\title{
Vestibular migraine: A case report and review of the literature
}

\author{
Vestibuler migren: Olgu sunumu ve literatürün gözden geçirilmesi
}

\author{
Bahar SAY, (D) Ufuk ERGÜN
}

\begin{abstract}
Summary
Vestibular migraine (VM) is one of the most common causes of episodic vertigo, but it can be missed in patients complaining of dizziness. This report describes the case of a 46-year-old woman with episodic vertigo attacks and a history of migrainous headaches. Some of the vertigo attacks were accompanied by a migraine. Gaze-induced nystagmus was present during attacks, but regressed with medication. Ear, nose, and throat evaluation; laboratory; imaging findings; and hearing test results were normal. Treatment with $500 \mathrm{mg}$ valproic acid led to a rapid response in this case. VM should be considered in neurological examinations on the basis of clinical symptomatology.
\end{abstract}

Keywords: Episodic vertigo; valproic acid; vestibular migraine.

\section{Özet}

Vestibuler migren epizodik vertigonun en sık nedenlerinden biridir ancak başdönmesi yakınmalarına sahip olgularda vestibüler migren tanısı atlanabilmektedir. Bu yazıda epizodik vertigo atakları ve özgeçmişinde migrenöz başağıları olan 46 yaşında kadın olguyu sunmayı amaçladık. Vertigo ataklarının bazılarına migrenöz vasıfta başağrısı eşlik ediyordu. Nörolojik değerlendirmesinde atak döneminde bakış ile indüklenen nistagmusu olup atak dışında normaldi. Kulak burun boğaz değerlendirmesi, laboratuar ve görüntüleme çalışmaları ile işitme testi normaldi. Klinik semptomatoloji temelinde vestibüler migren tanısı düşünüldü. Tedavide $500 \mathrm{mg}$ valproik asit ile hızlı yanıt alındı.

Anahtar sözcükler: Epizodik vertigo; valproik asit; vestibuler migren.

\section{Introduction}

Vestibular migraine (VM) is the frequent and rarely diagnosed caused of episodic vertigo. Therefore, its prevalence is not clearly known, but is estimated to be $4.3-29.3 \% .{ }^{[1]}$ It was previously named migraine-related vertigo, migraine-associated vestibulopathy and migrainous vertigo as well, and was defined as vestibular migraine by the members of Barany Society and the International Headache Society (IHS) in 2012. In 2013, the diagnostic criteria of the disease were published in the appendix of the International Classification of Headache Disorders 3 (ICHD-3) beta. ${ }^{[2,3]}$

\section{Case Report}

A 46-year-old woman had vertigo attacks of several seconds, triggered by movement for 5 months. She had increased and more frequent dizziness and in the last 2 months, which was prolonged for as long as 1 hour. Some of the attacks were accompanied by throbbing headache of half of the head with photophobia and phonophobia, which lasted for as long as 3 hours. Due to these complaints, she was previously evaluated in ear-nose-throat and neurology clinics of an external medical center, no pathology was determined in the examination and the laboratory findings, and her treatment was begun with betahistine dihydrochloride. Despite long-term therapy, she presented again to our clinic since her attacks persisted, and nausea-vomiting had accompanied her complaints for 15 days, and dizziness had become continuous for 2 days. Her history included non-aura migraine in three members of her family with an onset at the second decade. Her neurological examination included nystagmus with continuous, minimal rotational component gaze induced left direction. Cranial 
Magnetic Resonance Imaging (MRI), MRI venography, carotid-vertebral doppler ultrasonography, electroencephalography and blood analysis findings were all normal. No hearing loss was determined in the audiogram tests performed during the attack and the non-attack periods. The patient was considered to have VM and oral administration of valproic acid 500 mg was begun. $80 \%$ of the symptoms regressed at the $2^{\text {nd }}$ hour of medication, and the nystagmus disappeared. She had no attack under valproic acid therapy during her one-month follow-up, and the agent also had a positive effect on her emotional condition.

\section{Discussion}

Presence of dizziness and headache is a frequent cause of admissions to neurology clinics. VM is one of these causes. Its incidence among the general population is about $1 \%$ life-long and $0.9 \%$ annually. It is $1.5-5$ folds more common among women than men. Genetic heritance is not clear; however chromosomes $11 \mathrm{q}$ and $5 \mathrm{q} 35$ have been investigated recently for migraine-related vertigo. ${ }^{[4,5]}$ Despite numerous studies, the pathophysiology of VM is not clear. The main hypothesis on the subject includes the pathophysiology of migraine and the role of reciprocal connections between vestibular nuclei in the brain and structures regulating the trigeminal nociceptive inputs. ${ }^{[1,6]}$

In vestibular migraine, the onset of the symptoms is observed 5-10 years after the original onset of the migraine. ${ }^{[7,8]}$ Episodic attacks characteristically include spontaneous, positional or movement-induced vertigo, dizziness, feeling of imbalance, and migrainous headache (may be aura or non-aura). Dizziness and headache may be observed at different times or at the same time. Horizontal or vertical nystagmus, gaze-evoked (single direction or both directions) nystagmus, saccadic pursuit and central positional nystagmus may be observed in the attacks. ${ }^{[6]}$ In a study analyzing the contribution of nystagmus to the diagnosis of VM, the types of nystagmus observed in patients were analyzed, and it was concluded that every type of nystagmus may be observed in patients with VM, and that nystagmus may be induced positionally during the evaluation..$^{[9]}$ The laboratory findings of our case were normal, and the diagnosis of VM was made upon clinic symptomatology and history of migraine. Gaze-evoked nystag- mus was observed on the neurological examination in both directions during her attack. Neurological examination was normal during the non-attack period. This is important for the diagnosis of VM.

Diagnosis is vestibular migraine is made on the basis of clinical symptomatology. Therefore, the attacks of the patients should briefly be questioned for the differential diagnosis. The differential diagnosis includes basilar migraine, Meniere's disease, benign paroxysmal vertigo, transient ischemic attack. Vertigo attacks may be misjudged as migraine aura; however, aura may be distinguished by its relation to headache and its duration. ${ }^{[10]}$ Vertigo may accompany basilar migraine; however, according to the $\mathrm{ICDH}-2$ criteria, migrainous headache that is subsequent to a minimum of two posterior circulation findings that take 5-160 minutes may be present for basilar migraine. Furthermore, it has been reported that cases with basilar migraine have more severe vertigo attacks compared to vestibular migraine. ${ }^{[1]}$ While pulsatile, progressive hearing loss with vertigo attacks, accompanied by tinnitus and low-frequency hearing loss in the early period may indicate Meniere's disease, it is differentiated from VM this way. In addition to the similarity in the symptomatology between Meniere's disease and VM, Meniere's disease has been reported to be more common among patients with a history of migraine. ${ }^{[12]}$ Another pathology in the differential diagnosis is that the vertigo attacks take seconds in benign paroxysmal vertigo, and spontaneously end typically within weeks or a month, whereas in VM attacks that repeat frequently within a year takes long and no spontaneous improvement is expected. During the acute attacks of vertigo, the analysis of the positional nystagmus usually permits differentiation of positional VM from benign paroxysmal vertigo. ${ }^{[13]}$ Transient ischemic attack (TIA) is considered more frequently in later ages. Ischemic attack is different to VM, with other accompanying neurological findings, risk factors, and a pathological doppler ultrasonography. ${ }^{[1]}$

There is no consensus guideline for the treatment in VM, and the recommendations are based on randomized controlled studies, case reports, retrospective cohort studies and open label trials. In studies on tryptan use in acute attacks, almotryptan $12.5 \mathrm{mg}$ orally was found to be highly effective in relieving 
the vertiginous symptoms, sumatryptan (variable doses) was found to be effective, and zolmitryptan $2.5 \mathrm{mg}$ oral was found to be slightly effective. ${ }^{[14,15]}$ While antiemetic treatments (e.g. dimenhydrinate and benzodiazepine) are believed to be effective in acute attacks, the effect of methylprednisolone (1000 mg/day, 1-3 min.) in long-term use in serious episodes has also been reported. ${ }^{[16]}$ Prophylactic therapy includes acetazolamide, cinnarizine, flunarizine, lamotrigine, pizotifen, propranolol, rizatriptan, topiramate and valproic acid; drug selection may be made separately in each patient. ${ }^{[17,18]}$ In the study of Çeliker et al., valproic acid was found to be effective on the vestibular symptoms of patients with migraine, whereas in another study comparing venlafaxine and flunarizine, the efficacy of valproate on the vestibular symptoms was found to be lower compared to other agents. ${ }^{[19,20]}$ Our case had presented in the attack period with dizziness only, and did not benefit from intravenous dimenhydrinate therapy. However, a rapid response was observed to valproic acid $500 \mathrm{mg}$ oral, which was recommended during prophylactic therapy.

In conclusion, vestibular migraine should be considered in neurological examinations, history should be obtained in detail in patients presenting with dizziness, and diagnosed cases undergo attack therapy, and prophylactic therapy should also be recommended. The selection should be patient-specific in prophylactic therapy.

\section{Conflict-of-interest issues regarding the author- ship or article: None declared.}

Financial Disclosure: The authors declared that this study has received no financial support.

\section{Peer-rewiew: Externally peer-reviewed.}

\section{References}

1. Sohn JH. Recent Advances in the Understanding of Vestibular Migraine. Behav Neurol 2016;2016:1801845. [CrossRef]

2. Lempert T, Olesen J, Furman J, Waterston J, Seemungal B, Carey J, et al. Vestibular migraine: diagnostic criteria. J Vestib Res 2012;22(4):167-72. [CrossRef]

3. Headache Classification Committee of the International Headache Society (IHS). The International Classification of
Headache Disorders, $3^{\text {rd }}$ edition (beta version). Cephalalgia 2013;33(9):629-808. [CrossRef]

4. Lee $\mathrm{H}$, Jen JC, Cha YH, Nelson SF, Baloh RW. Phenotypic and genetic analysis of a large family with migraine-associated vertigo. Headache 2008;48(10):1460-7. [CrossRef]

5. Bahmad F Jr, DePalma SR, Merchant SN, Bezerra RL, Oliveira CA, Seidman CE, et al. Locus for familial migrainous vertigo disease maps to chromosome 5q35. Ann Otol Rhinol Laryngol 2009;118(9):670-6. [CrossRef]

6. O'Connell Ferster AP, Priesol AJ, Isildak H. The clinical manifestations of vestibular migraine: A review. Auris Nasus Larynx. 2017;44(3):249-52. [CrossRef]

7. Munro-Porchet $S$. Supportive care in cancer patients, $2^{\text {nd }}$ International Symposium, St. Gallen, Switzerland--March 1-3, 1990. J Palliat Care 1990;6(3):45-6. [CrossRef]

8. Dieterich M, Obermann M, Celebisoy N. Vestibular migraine: the most frequent entity of episodic vertigo. J Neurol 2016;263(Suppl 1):S82-9. [CrossRef]

9. Polensek SH, Tusa RJ. Nystagmus during attacks of vestibular migraine: an aid in diagnosis. Audiol Neurootol 2010;15(4):241-6. [CrossRef]

10. Furman JM, Marcus DA, Balaban CD. Vestibular migraine: clinical aspects and pathophysiology. Lancet Neurol 2013;12(7):706-15. [CrossRef]

11. Wang CT, Lai MS, Young YH. Relationship between basilar-type migraine and migrainous vertigo. Headache 2009;49(3):426-34. [CrossRef]

12. Radtke A, Lempert T, Gresty MA, Brookes GB, Bronstein AM, Neuhauser $\mathrm{H}$. Migraine and Ménière's disease: is there a link? Neurology 2002;59(11):1700-4. [CrossRef]

13. Barbosa F, Villa TR. Vestibular migraine: diagnosis challenges and need for targeted treatment. Arq Neuropsiquiatr 2016;74(5):416-22. [CrossRef]

14. Lauritsen CG, Marmura MJ. Current Treatment Options:Vestibular Migraine. Curr Treat Options Neurol 2017;19(11):38.

15. Bikhazi P, Jackson C, Ruckenstein MJ. Efficacy of antimigrainous therapy in the treatment of migraine-associated dizziness. Am J Otol 1997;18(3):350-4.

16. Prakash S, Shah ND. Migrainous vertigo responsive to intravenous methylprednisolone: case reports. Headache 2009;49(8):1235-9. [CrossRef]

17. Salmito MC, Duarte JA, Morganti LOG, Brandão PVC, Nakao $\mathrm{BH}$, Villa TR, et al. Prophylactic treatment of vestibular migraine. Braz J Otorhinolaryngol 2017;83(4):404-10. [CrossRef]

18. Fotuhi M, Glaun B, Quan SY, Sofare T. Vestibular migraine: a critical review of treatment trials. J Neurol 2009;256(5):7116. [CrossRef]

19. Celiker A, Bir LS, Ardiç N. Effects of valproate on vestibular symptoms and electronystagmographic findings in migraine patients. Clin Neuropharmacol 2007;30(4):213-7.

20. Liu F, Ma T, Che X, Wang Q, Yu S. The Efficacy of Venlafaxine, Flunarizine, and Valproic Acid in the Prophylaxis of Vestibular Migraine. Front Neurol 2017;8:524. [CrossRef] 